\title{
Perineal Hernia Repair Using an Autologous Tunica Vaginalis Communis in Nine Intact Male Dogs
}

\author{
Kittiya PRATUMMINTRA ${ }^{1)}$, Suwicha CHUTHATEP(1), Wijit BANLUNARA ${ }^{2)}$ and Marissak KALPRAVIDH ${ }^{1) *}$ \\ 1) Department of Surgery, Faculty of Veterinary Science, Chulalongkorn University, Bangkok 10330, Thailand \\ ${ }^{2)}$ Department of Pathology, Faculty of Veterinary Science, Chulalongkorn University, Bangkok 10330, Thailand
}

(Received 24 October 2011/Accepted 20 October 2012/Published online in J-STAGE 6 November 2012)

ABSTRACT. Perineal hernia in dogs is very problematic and mostly requires surgical reconstruction of the weak pelvic diaphragm. Tissue or synthetic grafts have been used for the correction after failure of the conventional herniorrhaphy. Aim of this clinical trial was to assess the possible use of the autologous tunica vaginalis communis as a free graft for perineal hernia repair in intact male dogs. Seven unilateral and 2 bilateral perineal hernias in nine intact male dogs free from testicular and scrotal neoplasms were included in this study. The median surgical time for unilateral herniorrhaphy was $75 \mathrm{~min}$. The median follow-up time was 13 months. The success of the autografting, based on no recurrence and comfort of the animals during urination and defecation, was found in ten of 11 hernias; giving a success rate of $90.91 \%$. One hernia (9.09\%) recurred 10 days after surgery. Histopathological examination of the apposing area between the graft and the adjacent tissue, taken during the repair of the recurred case at day 20, revealed neovascularization and connective tissue ingrowth. In conclusion, the tunica vaginalis autograft can be used for perineal herniorrhaphy in intact male dogs.

KEY WORDS: autograft, canine, herniorrhaphy, perineal hernia, tunica vaginalis.

doi: 10.1292/jvms.11-0478; J. Vet. Med. Sci. 75(3): 337-341, 2013

Perineal hernia $(\mathrm{PH})$ is a protrusion of the abdominal organs into the perineal area through the weak pelvic diaphragm; consisting of the coccygeal and levator ani muscles. It occurs commonly in aging male dogs and rarely in females [3]. Straining to defecate and perineal swelling are the most consistent clinical signs [4]. The swelling is usually obvious and may be unilateral or bilateral. Chronic tenesmus may lead to caudal displacement of the prostate and urinary bladder.

Temporary alleviation of PH may be obtained from conservative management including the use of stool softeners, periodic enemas and digital fecal removal [4]. However, most cases require surgical treatment to prevent life-threatening complications from the incarceration of herniated organs, especially the urinary bladder. According to Orcher [19], an appositional herniorrhaphy, re-suturing of the weak muscles of the pelvic diaphragm, was first reported in the 1950s. Since then, there have been several reports using this technique with recurrence rates of $10-46 \%[2,6,12,21,27$, 29]. Among the techniques attempted to avoid reherniation, transposition of the internal obturator muscle (TIOM) is the most reliable technique and considered now the conventional herniorrhaphy. The transposed muscle increases strength of the ventral perineum where most hernias occur $[11,19,24,27,28]$. The reports on the herniorrhaphy utilizing other patient's own tissues for closing the defect include transposition of the superficial gluteal muscle [22, 29], semitendinosus muscle [8] and fascia lata [5]. The synthetic and

*Correspondence to: Kalpravidh, M., Department of Surgery, Faculty of Veterinary Science, Chulalongkorn University, Bangkok 10330, Thailand.e-mail: marissak.k@chula.ac.th

C2013 The Japanese Society of Veterinary Science biological materials that have been reported for $\mathrm{PH}$ repair in dogs are a polypropylene mesh $[9,26,28]$ and porcine small intestinal submucosa [25].

Tunica vaginalis communis is derived from the peritoneum which is composed of mesothelium and connective tissue [32]. It was experimentally used as an autologous, homologous or heterologous graft for reconstruction of the urethral defects in rabbits [7, 16], abdominal wall defects in rats [10], umbilical hernias in sheep [1] and urinary bladder wall defects in dogs [31]. Use of the autologous tunica vaginalis communis as a pedicled flap for $\mathrm{PH}$ repair has been reported in one dog [23]. Our study hypothesized that a free flap of the autologous tunica vaginalis harvested right before herniorrhaphy could be used for $\mathrm{PH}$ repair in dogs.

\section{MATERIALS AND METHODS}

Dogs and PH: Dogs included in this study were presented with $\mathrm{PH}$ at the Small Animal Hospital, Faculty of Veterinary Science, Chulalongkorn University, Bangkok, Thailand. Criteria for case selection were 1) intact male dogs; 2) no neoplasms of the testicles and scrotum; 3) permission of the dogs' owners for the application of the autografting procedure in their dogs. History, signalment, physical and radiographic examinations of the perineum were recorded.

Anesthesia: The animals were premedicated with morphine (the Food and Drug Administration, Bangkok, Thailand) at $0.4 \mathrm{mg} / \mathrm{kg}$ IM and acepromazine (Combistress ${ }^{\circledR}$, Phenix Pharmaceuticals NV, Antwerp, Belgium) at 0.02 $\mathrm{mg} / \mathrm{kg}$ IM. General anesthesia was induced to effect with $1 \%$ propofol IV (Fresofol ${ }^{\circledR}$, Fresenius Kabi Austria GmbH, Graz, Austria). The animals were then intubated, and anesthesia was maintained with isoflurane (Forane $^{\circledR}$, Abbott Laboratories Ltd., Kent, England) in oxygen and epidural 
$0.5 \%$ bupivacaine (Marcain ${ }^{\circledR}$, AstraZeneca Pty Ltd., North Ryde, NSW, Australia) at $0.2 \mathrm{ml} / \mathrm{kg}$. Preoperatively, the dog received enrofloxacin (Baytril ${ }^{\circledR}$, Bayer Korea Ltd., Ansan, Korea) at $5 \mathrm{mg} / \mathrm{kg} \mathrm{SC}$. Anesthesia depth, electrocardiogram, heart rate, respiratory rate, $\mathrm{O}_{2}$ saturation and blood pressures were monitored during surgery until complete recovery. A lubricated gauze was inserted into the rectum, and a purse string suture was aseptically placed around the anus. The skin at the prescrotal and perineal areas, the caudal aspect of the hind legs, and base of the tail, were liberally clipped and aseptically prepared for surgery.

Castration and preparation of the tunica vaginalis communis graft: The dogs were placed in dorsal recumbency, and closed castration was performed through a prescrotal incision. The tunica vaginalis communis was harvested, dissected free of fat, cut along the greater curvature of the testis and immersed in isotonic saline solution until use.

Perineal herniorrhaphy: The dog was positioned in ventral recumbency with the tail pulled and fixed over the back, the pelvis elevated and the hind legs padded against the table. After surgical scrub, the perineal area excluding the anus was draped. A slightly curved dorsoventral skin incision was made over the hernia, extending from the lateral tail base down to the medial angle of the ischial tuberosity. The subcutaneous tissue and hernial sac were incised. The herniated organs were identified and returned to their anatomic locations. The internal pudendal artery and vein, pudendal nerve, caudal rectal vessels and nerve, external anal sphincter, rectum, sacrotuberous ligament, the coccygeal, internal obturator and levator ani muscles were identified. The prepared tunica vaginalis was cut into nearly triangular shape with its base of 3-4 cm wide. Then, the graft was inserted caudocranially underneath the coccygeal muscle until its cranial rim reached the sacrotuberous ligament at the cranial border of the muscle (Fig. 1). Sutures were then placed but untied at approximately $0.5 \mathrm{~cm}$ interval. Starting at the dorsal aspect of the defect, the first 3 to 4 simple interrupted sutures of 0-2/0 monofilament nonabsorbable polypropylene material (Prolene ${ }^{\mathrm{TM}}$, Ethicon Inc., Somerville, NJ, U.S.A.) were placed to anchor the graft to the coccygeal muscle and sacrotuberous ligament. The sutures were passed through the ligament with care to avoid the caudal gluteal vessels and sciatic nerve passing cranial to the ligament. Three to 4 sutures were inserted medially from the graft to the external anal sphincter and ventrally to the internal obturator muscle. Suturing had to be careful to avoid biting the needle into the rectum and the anal sac. All sutures were then tied starting from dorsal to ventral. The redundant edge of the graft was trimmed, and the subcutaneous tissues were closed over the graft using simple interrupted 2/0-3/0 absorbable polydioxanone (PDS ${ }^{\mathrm{TM}} \mathrm{II}$, Ethicon, Johnson\&Johnson Intl., St-Stevens-Woluwe, Belgium) sutures. The skin incision was closed by simple interrupted sutures of 2/0-3/0 monofilament nonabsorbable polyamide material (Dafilon ${ }^{\mathrm{TM}}, \mathrm{B} /$ BRAUN Aesculap AG, Tuttlingen, Germany). The purse string suture and the tampon were then removed. The animals were given enrofloxacin at $5 \mathrm{mg} / \mathrm{kg}$ orally s.i.d. for 7 days and tramadol at $4 \mathrm{mg} / \mathrm{kg}$ orally b.i.d. for 5 days. Stitches

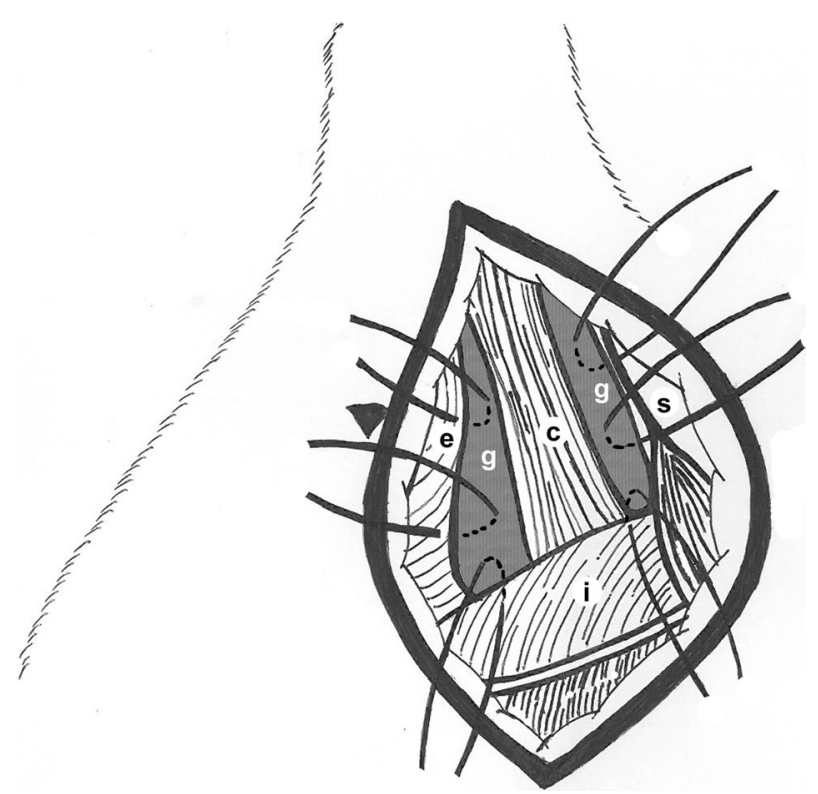

Fig.1. The tunica vaginalis graft (g) was inserted under the coccygeal muscle (c) and sutured to the sacrotuberous ligament (s), external anal sphincter (e) and internal obturator muscle (i). $173 \times 153 \mathrm{~mm}(300 \times 300 \mathrm{DPI})$

were removed 10 days after surgery.

Follow-up was made by periodic examination and telephone calls every 1 week for 2 months and then every 4 weeks for a minimum of 6 months. Urination and defecation behavior were observed. Tenesmus was subjectively assessed by the dog owners. Radiographs were taken at 3 and 6 months after surgery. No PH recurrence and comfort of the animals in relation to urination and defecation were determined as the success of $\mathrm{PH}$ repair with the tunica vaginalis autograft. Surgical time was measured from the start of castration to the end of herniorrhaphy.

\section{RESULTS}

Table 1 shows dog breeds, age at first presentation, weight, type of $\mathrm{PH}$, herniation duration, clinical signs, herniated organs and rectal and prostate abnormalities. Median values of animal age, weight and herniation duration were 10 years (range, 5-11), $6.55 \mathrm{~kg}$ (range, 4.05-16.4) and 2.5 months (range, 1-8), respectively. Seven dogs had unilateral (right, 4; left, 3) and two had bilateral PH. On presentation, most dogs had combined clinical signs. Most cases were initially managed by diet change and bowel lubricants and referred for surgery after unsuccessful treatment of the constipation.

The median surgical time for unilateral herniorrhaphy was $75 \mathrm{~min}$ (range, 55-110). The surgical times for bilateral herniorrhaphies in two dogs were 65 and $135 \mathrm{~min}$. The median follow-up time was 13 months (range, 10-15.75). The success of $\mathrm{PH}$ repair with the tunca vaginalis autografting was observed in ten hernias (90.91\%). PH recurrence was found in one dog 10 days after surgery, giving a recurrence 
Table 1. Signalment, perineal hernia description, concurrent abnormalities and surgical treatment of 11 hernias in nine dogs

\begin{tabular}{|c|c|c|c|c|c|c|c|c|c|c|}
\hline Breeds & $\begin{array}{l}\text { Age } \\
\text { (years) }\end{array}$ & $\begin{array}{l}\text { Weight } \\
\text { (kg) }\end{array}$ & $\begin{array}{l}\text { Side of } \\
\text { hernia }\end{array}$ & $\begin{array}{r}\text { Duration } \\
\text { (months) }\end{array}$ & $\begin{array}{c}\text { Urination and } \\
\text { defecation } \\
\text { abnormalities }\end{array}$ & $\begin{array}{c}\text { Rectal } \\
\text { abnormalities }\end{array}$ & $\begin{array}{c}\text { Prostatic } \\
\text { abnormalities }\end{array}$ & $\begin{array}{l}\text { Surgical } \\
\text { time (min)* }\end{array}$ & $\begin{array}{l}\text { Follow-up } \\
\text { (months) }\end{array}$ & $\begin{array}{l}\text { Recurrence } \\
\text { of hernia }\end{array}$ \\
\hline Mixed & 10 & 16.4 & Right & 1 & Tenesmus & Dilation & Prostatomegaly & 65 & 10 & No \\
\hline Mixed & 11 & 6.55 & Left & 2.5 & Tenesmus & Deviation & No & 55 & 12.5 & No \\
\hline Mixed & 5 & 12.5 & Left & 5 & Tenesmus & Dilation & No & 105 & 15 & No \\
\hline Poodle & 10 & 9.5 & Right & 2 & $\begin{array}{c}\text { Tenesmus and } \\
\text { hematuria }\end{array}$ & $\begin{array}{l}\text { Deviation, dilation, } \\
\text { and prolapse }\end{array}$ & No & 75 & 13 & No \\
\hline Poodle & 10 & 6.55 & Left & 2.5 & Tenesmus & Dilation & No & 110 & 14.5 & No \\
\hline Shih tzu & 6 & 6.15 & Right & 1 & Tenesmus & Deviation & No & 70 & 11.5 & No \\
\hline Shih tzu & 5 & 6.8 & Right & 1.5 & Hematochezia & $\begin{array}{l}\text { Deviation and } \\
\text { dilation }\end{array}$ & Prostatomegaly & 75 & 15.5 & No \\
\hline Shih tzu & 8 & 4.05 & Bilateral & 5 & Tenesmus & $\begin{array}{l}\text { Deviation and } \\
\text { dilation }\end{array}$ & Prostatomegaly & $\begin{array}{l}\text { Right: } 35 \\
\text { Left: } 30\end{array}$ & 10.5 & No \\
\hline Mixed & 10 & 4.85 & Bilateral & 8 & $\begin{array}{c}\text { Tenesmus and } \\
\text { dysuria }\end{array}$ & $\begin{array}{l}\text { Deviation and } \\
\text { dilation }\end{array}$ & No & $\begin{array}{l}\text { Right: } 75 \\
\text { Left: } 60\end{array}$ & 15.75 & $\begin{array}{l}10 \text { days after } \\
\text { surgery }\end{array}$ \\
\hline
\end{tabular}

*Measured from the start of castration to the end of perineal hernia repair

rate of $9.09 \%$. Reherniation occurred at the ventral perineum where the graft was detached from the internal obturator muscle. The recurred hernia was repaired 20 days after the first surgery at which the apposing area between the graft and the adjacent muscle was biopsied. Histopathological examination of the tissue sample revealed neovascularization and connective tissue ingrowth.

Right after herniorrhaphy, rectal prolapse and rectal deviation were resolved from all affected dogs, while rectal dilation remained. No difficulty of urination was noted during follow up. At day 10 after the operation, slight defecation difficulty was found in two dogs including the one with the reherniation. The defecation problem was resolved in one dog 3 months later, but still slightly remained in the dog with the recurred $\mathrm{PH}$.

\section{DISCUSSION}

The present study has shown that tunica vaginalis communis is a suitable material for $\mathrm{PH}$ repair in dogs. Besides strengthening the pelvic diaphragm, the autograft has the advantages of no antigenic property and less cost when compared with the synthetic material, and it could be obtained from closed castration right before herniorrhaphy. Compared with the autologous fascia lata [5], harvest of the tunica vaginalis is easier and does not require additional surgical site, since routine castration is a part of $\mathrm{PH}$ treatment. In addition, it is associated with minor morbidity of the donor site. However, this technique is applicable only in the intact male dogs, while $\mathrm{PH}$ repair with the fascia lata or porcine small intestinal submucosa can be performed in females and either castrated or intact male dogs. This technique should not be applied in dogs with testicular neoplasia otherwise spread of the malignancy may occur. However, this study did not histopathologically examine the testicles removed from all dogs to rule out the neoplasia which could not be determined by gross examination alone.

TIOM is the conventional procedure for $\mathrm{PH}$ repair, while use of the prosthetic material is reserved for reherniation. The recurrence rates have been reported from zero to $18.75 \%$ after TIOM [11, 19, 24, 27, 28], and zero to $12.5 \%$ after the use of a polypropylene mesh [9, 26, 28]. Principally, a surgeon should avoid the technique using foreign material when one utilizing the patient's own tissue is possible [28]. The tunica vaginalis autograft serves this principle as evidenced in the present study. Use of this graft as a free flap for $\mathrm{PH}$ repair is less technical than the use of the pedicle graft inserted to the perineal area via the abdominal cavity previously reported [23]. However, the latter graft has the advantage of the remained vascularity. The free tunica vaginalis graft lacks of blood supply and is early necrotized. It might be changed in the same way as that is found with the free skin graft. The free graft must survive by absorbing tissue fluid from the adjacent muscle by capillary action during the first $48 \mathrm{hr}$ after transplantation. Capillaries from the adjacent muscle unite with the graft to re-establish circulation. New capillaries later grow into the graft and fibrous connective tissue forms to hold the graft in place [20]. This is supported by the histopathological finding of the apposing area between the graft and the adjacent muscle retrieved during reherniation correction in one dog. In the present study, the graft was passed under the coccygeal muscle to anchor and to help revascularization of the graft.

The follow-up time of 6 months is adequate. Reherniation occurring beyond this interval is more likely to be associated with continued deterioration of the muscles and other tissues in the perineal area rather than failure of the graft. In assessing the success of herniorrhaphy, not only the reherniation but also the postoperative comfort of the animal should be determined [19]. Rectal abnormalities have potential for continued straining and resulting herniorrhaphy failure. After $\mathrm{PH}$ correction, rectal deviation and rectal prolapse were resolved in all dogs. Distortion of the rectum was minimized by suturing the external anal sphincter with the graft instead of with the levator ani and coccygeal muscles and the sacrotuberous ligament as in the appositional herniorrhaphy.

Relaxin is possibly a local factor in weakening the pelvic diaphragm muscles and subsequent $\mathrm{PH}$ formation [18]. 
Compared with clinically normal dogs, higher relaxin receptors were found within the muscles of the pelvic diaphragm of dogs with $\mathrm{PH}$, and castration should be done to eliminate the effect of relaxin on $\mathrm{PH}$ pathogenesis [17]. The relaxin hormone of many species is synthesized in the prostate gland and secreted into the seminal plasma [30]. Castration must be performed especially in prostatomegaly to decrease the level of relaxin to prevent recurrence. In the present study, large prostates were found in three dogs which had to be castrated not only to minimize the risk of reherniation but also to treat the large gland. Castration can permanently involute the prostatic hyperplasia within 3 to 12 weeks [14]. There is convincing evidence that the risk of $\mathrm{PH}$ recurrence for non-castrated dogs is 2.7 times greater than that for castrated dogs [13]. In addition, recurred $\mathrm{PH}$ was reported in two $(10 \%)$ of 19 non-castrated and four $(5 \%)$ of 79 castrated male dogs [15].

ACKNOWLEDGMENTS. This study was financially supported by the Department of Surgery, Faculty of Veterinary Science and the Graduate School, Chulalongkorn University, Bangkok, Thailand. We thank Dr. Sunsanee Pankhum for her surgical assistance.

\section{REFERENCES}

1. Abass, B. T. 2008. Bovine tunica vaginalis: a new material for umbilical hernioplasty in sheep. Iraqi. J. Vet. Sci. 22: 69-76.

2. Bellenger, C. R. 1980. Perineal hernia in dogs. Aust. Vet. J. 56: 434-438. [Medline] [CrossRef]

3. Bellenger, C. R. and Canfield, R. B. 2002. Perineal hernia. pp. 487-498. In: Textbook of Small Animal Surgery. 3 rd ed. (Slatter, D. ed.), Saunders, Philadelphia.

4. Bojrab, M. J. and Toomey, A. 1981. Perineal herniorrhaphy. Compend. Contin. Educ. Vet 3: 8-15.

5. Bongartz, A., Carofiglio, F., Balligand, M., Heimann, M. and Hamaide, A. 2005. Use of autogenous fascia lata graft for perineal herniorrhaphy in dogs. Vet. Surg. 34: 405-413. [Medline] [CrossRef]

6. Burrows, C. F. and Harvey, C. E. 1973. Perineal hernia in the dog. J. Small Anim. Pract. 14: 315-332. [Medline] [CrossRef]

7. Calado, A. A., Macedo, A. Jr., Delcelo, R., de Figueiredo, L. F. P., Ortiz, V. and Srougi, M. 2005. The tunica vaginalis dorsal graft urethroplasty: experimental study in rabbits. J. Urol. 174: 765-770. [Medline] [CrossRef]

8. Chambers, J. N. and Rawlings, C. A. 1991. Applications of a semitendinosus muscle flap in two dogs. J. Am. Vet. Med. Assoc. 199: 84-86. [Medline]

9. Clarke, R. E. 1989. Perineal herniorrhaphy in the dog using polypropylene mesh. Aust. Vet. Pract. 19: 8-14.

10. Hafeez, Y. M., Zuki, A. B. Z., Loqman, M. Y., Noordin, M. M. and Norimah, Y. 2005. Comparative evaluations of the processed bovine tunica vaginalis implant in a rat model. Anat. Sci. Int. 80: 181-188. [Medline] [CrossRef]

11. Hardie, E. M., Kolata, R. J., Earley, T. D., Rawlings, C. A. and Gorgacz, E. J. 1983. Evaluation of internal obturator muscle transposition in treatment of perineal hernia in dogs. Vet. Surg. 12: 69-72. [CrossRef]

12. Harvey, C. E. 1977. Treatment of perineal hernia in the dog a reassessment. J. Small Anim. Pract. 18: 505-511. [Medline] [CrossRef]
13. Hayes, H. M., Wilson, G. P. and Tarone, R. E. 1978. The epidemiologic features of perineal hernias in 771 dogs. J. Am. Anim. Hosp. Assoc. 14: 703-707.

14. Hedlund, C. S. 2007. Surgery of the male reproductive tract. pp. 747-754. In: Small Animal Surgery, 3rd ed. (Fossum, T. W., Hedlund, C. S., Johnson, A. L., Schulz, K. S., Seim, H. B., Willard, M. D., Bahr, A. and Carroll, G. L. eds.), Mosby, St. Louis.

15. Hosgood, G., Hedlund, C. S., Pechman, R. D. and Dean, P. W. 1995. Perineal herniorrhaphy: perioperative data from 100 dogs. J. Am. Anim. Hosp. Assoc. 31: 331-342. [Medline]

16. Leslie, B., Barboza, L. L., Souza, P. O., Silva, P. S., Delcedo, R., Ortiz, V. and Macedo, A. Jr. 2009. Dorsal tunica vaginalis graft plus onlay preputial island flap urethroplasty: experimental study in rabbits. J. Pediatr. Urol. 5: 93-99. [Medline] [CrossRef]

17. Merchav, R., Feuermann, Y., Shamay, A., Ranen, E., Stein, U., Johnston, D. E. and Shahar, R. 2005. Expression of relaxin receptor LRG7, canine relaxin, and relaxin-like factor in the pelvic diaphragm musculature of dogs with and without perineal hernia. Vet. Surg. 34: 476-481. [Medline] [CrossRef]

18. Niebauer, G. W., Shibly, S., Seltenhammer, M., Pirker, A. and Brandt, S. 2005. Relaxin of prostatic origin might be linked to perineal hernia formaton in dogs. Ann. N. Y. Acad. Sci. 1041: 415-422. [Medline] [CrossRef]

19. Orsher, R. J. 1986. Clinical and surgical parameters in dogs with perineal hernia: analysis of results of internal obturator transposition. Vet. Surg. 15: 253-258. [CrossRef]

20. Pavletic, M. 1993. Free grafts. pp. 241-261. In: Atlas of Small Animal Reconstructive Surgery, J.B. Lippincott Co., Philadelphia.

21. Pettit, G. D. 1962. Perineal hernia in the dog. Cornell Vet. 52: 261-279. [Medline]

22. Spreull, J. S. A. and Frankland, A. L. 1980. Transplanting the superficial gluteal muscle in the treatment of perineal hernia and flexure of the rectum in the dog. J. Small Anim. Pract. 21: 265-278. [Medline] [CrossRef]

23. Tanaka, S., Asano, K., Yamaya, Y., Sato, T., Tsumagari, S. and Nagaoka, K. 2004. Reconstructive surgery of the pelvic diaphragm using the tunica vaginalis communis in a dog with perineal hernia. Jpn. J. Vet. Med. Assoc. 57: 451-454.

24. Sjollema, B. E. and Sluijs, F. J. 1989. Perineal hernia repair in the dog by transposition of the internal obturator muscle. II. Complications and results in 100 patients. Vet. Q. 11: 18-23. [Medline] [CrossRef]

25. Stoll, M. R., Cook, J. L., Pope, E. R., Carson, W. L. and Kreeger, J. M. 2002. The use of porcine small intestinal submucosa as a biomaterial for perineal herniorrhaphy in the dog. Vet. Surg. 31: 379-390. [Medline] [CrossRef]

26. Szabo, S., Wilkens, B. and Radasch, R. M. 2007. Use of polypropylene mesh in addition to internal obturator transposition: a review of 59 cases (2000-2004). J. Am. Anim. Hosp. Assoc. 43: 136-142. [Medline]

27. Vnuk, D., Lipar, M., Maticic, D., Smolec, O., Pecin, M. and Brkic, A. 2008. Comparison of standard perineal herniorrhaphy and transposition of the internal obturator muscle for perineal hernia repair in the dog. Veterinarski Arh. 78: 197-207.

28. Vnuk, D., Maticic, D., Kreszinger, M., Radisic, B., Kos, J., Lipar, M. and Babic, T. 2006. A modified salvage technique in surgical repair of perineal hernia in dogs using polypropylene mesh. Veterinarni Medicina 51: 111-117.

29. Weaver, A. D. and Omamegbe, J. O. 1981. Surgical treatment of perineal hernia in the dog. J. Small Anim. Pract. 22: 749-758. [Medline] [CrossRef] 
30. Weiss, G. 1989. Relaxin in the male. Biol. Reprod. 40: 197-200. [Medline] [CrossRef]

31. Wongsetthachai, P., Pramatwinai, C., Banlunara, W. and Kalpravidh, M. 2011. Urinary bladder wall substitution using autologous tunica vaginalis in male dogs. Res. Vet. Sci. 90: 156-159
[CrossRef]. [Medline]

32. Wrobel, K. H. 1998. Male reproductive system. pp. 226-227. In: Textbook of Veterinary Histology, 5th ed. (Dellmann, H.D. and Eurell, J.A. eds.), Williams \& Wilkins, Philadelphia. 